\begin{tabular}{|l|l|l||}
\hline \multicolumn{2}{|c|}{ PublisherInfo } \\
\hline \hline PublisherName & $:$ & BioMed Central \\
\hline \hline PublisherLocation & $:$ & London \\
\hline \hline PublisherImprintName & $:$ & BioMed Central \\
\hline \hline
\end{tabular}

\title{
A key enzyme upregulating collagen production by scleroderma
} fibroblasts

\begin{tabular}{|l|l|l||}
\hline \multicolumn{2}{|c|}{ ArticleInfo } \\
\hline \hline ArticleID & $:$ & 286 \\
\hline \hline ArticleDOI & $:$ & $10.1186 /$ ar-2002-74702 \\
\hline \hline ArticleCitationID & $:$ & 74702 \\
\hline \hline ArticleSequenceNumber & $:$ & 39 \\
\hline \hline ArticleCategory & $:$ & Paper Report \\
\hline \hline ArticleFirstPage & $:$ & 1 \\
\hline \hline ArticleLastPage & $:$ & 3 \\
\hline \hline & & RegistrationDate : 2002-1-16 \\
ArticleHistory & $:$ & Received \\
\hline \hline ArticleCopyright & $:$ & Biomed Central Ltd2002-16 \\
\hline \hline ArticleGrants & $:$ & \\
\hline \hline
\end{tabular}




\begin{tabular}{|l|l|l|l|}
\hline ArticleContext & $:$ & 130754411 \\
\hline
\end{tabular}

\section{Hideto Kameda Tsutomu Takeuchi, ${ }^{\text {Aff1 }}$}

Aff1 Saitama Medical Center, Saitama, Japan

\section{Keywords}

\section{Context}

Systemic sclerosis ( $\mathrm{SSc}$ ) is a fibroproliferative autoimmune disease characterized by the excessive production and deposition of collagen in skin and internal organs. Acting through specific transmembrane receptors, transforming growth factor-? (TGF-?) is known to play a crucial role in the development of tissue fibrosis. The authors had previously identified several signaling molecules other than Smad proteins including protein kinase C-d (PKC-d) as candidates downstream of TGF-? receptors. The aim of the present study was to examine the possible role of PKC-d in the upregulation collagen gene expression in SSc dermal fibroblasts.

\section{Significant findings}

Compared to normal fibroblasts, SSc dermal fibroblasts had increased type I and III collagen mRNA and protein as well as upregulation of PKC-d protein. Rottlerin, a specific inhibitor of PKC-d, inhibited collagen gene expression in both normal and SSc fibroblasts. Moreover, this study identified a 129-bp promoter region of the type I collagen gene encompassing nucleotides -804 to -675 which was responsive to the transcriptional inhibition by rottlerin and dominant-negative PKC-d expression.

\section{Comments}

These results indicate that PKC-d is a key molecule in the upregulation of type I collagen expression. However, the number of samples obtained from normal and SSc skins was too small to show a significant difference in the amounts of collagen and PKC-d expressed. In addition, most of the results 
presented in this paper relied on a single "selective" inhibitor of PKC-d, rottlerin. The following points should be addressed in future studies: 1) identification of transcription factors downstream of PKC-d that interact with a promoter segment encompassing nucleotides -804 -675; 2) comparison of PKC-d activity between SSc and normal fibroblasts; 3) possible differences in collagen and PKC-d expression among subgroups of SSc (e.g., diffuse cutaneous SSc and limited cutaneous SSc).

\section{Methods}

ELISA, collagenase digestion assay, northern blotting, in vitro nuclear transcription assay, chloramphenicol acetyl transferase gene assay, high-resolution fluorescence immunomicroscopy, western blotting

\section{Additional information}

\section{References}

1. Jimenez SA, Gaidarova S, Saitta B, Sandorfi N, Herrich DJ, Rosenbloom JC, Kucich U, Abrams WR, Rosenbloom J: Role of protein kinase C-d in the regulation of collagen gene expression in scleroderma fibroblasts. J Clin Invest . 2001, 108: 1395-1403.

This PDF file was created after publication. 